\title{
SHOOTING AT VIRTUE ${ }^{1}$
}

\author{
Jaanus Sooväli (Tartu Ülikool) ${ }^{2}$ \\ jaanus.soovali@ut.ee
}

\begin{abstract}
Nietzsche is known as a great and poignant critic of the JudeoChristian virtue and morality, but the motivation and aim of his criticisms might sometimes remain unclear. For instance, in Twilight of the Idols, he writes: "Are we harming virtue, we immoralists? - Just as little as anarchists harm princes. Princes sit securely on their thrones only after they've been shot at. Moral: morality must be shot at." This saying seems to suggest that Nietzsche criticized and attacked traditional virtue and morality in order to consolidate and strengthen them. In the article, I provide an interpretation of this saying and, in the course of it, approach Nietzsche's reconceptualization of virtue and morality more generally.
\end{abstract}

Keywords: Nietzsche; morality; virtue; immoralism.

\section{INTRODUCTION}

Nietzsche's attacks against, and criticism of, the Greek as well as Christian virtue and morality are well known, but for some reason he never gave up the word "virtue" itself and continues to use it until his last works. In Twilight of the Idols, he even writes: "Are we harming virtue, we immoralists? - Just as little as anarchists harm princes. Princes sit securely on their thrones only after they've been shot at.

\footnotetext{
${ }^{1}$ Recebido: 28-08-2016/ Aceito: 26-12-2016/ Publicado on-line: 19-01-2017.

${ }^{2}$ Jaanus Sooväli é Professor na Universidade de Tartu, Tartu, Estônia.
} 
Moral: morality must be shot at." (TI, Arrows and Epigrams 36) In the following, I will provide an interpretation of this arrow, and by doing so, approach Nietzsche's reconceptualization of virtue more generally.

This saying or arrow - one should ask immediately: directed towards which goal? - appears to be clear enough: by shooting at the princes, anarchists help them actually firmly back on their thrones; and so should also morality be shot at to help it back on its throne, to make it vigorous again. It seems as though Nietzsche and other immoralists, far from wishing to abolish and destroy morality, would like to reinforce it. But what kind of virtue and morality? The same old morality "that has attained dominance and validity in the form of morality as such" (EH, Why I am a destiny 4), the Judeo-Christian morality? If Nietzsche uses the word "morality" without any qualification, it usually refers to this morality. Also: are morality and virtue one and the same thing for Nietzsche? Our arrow gives us exactly such an impression - in the beginning, it names virtue, in the end, morality. In general, the two are, of course, closely linked any morality demands or propagates certain virtues, certain more or less constant human characteristics that are considered to be good and desirable; in Nietzsche's corpus, however, one can also find moraline-free virtues (cf. A 2). What kind morality and virtue is meant here?

Further, is it Nietzsche expressing his intention of wishing to help morality back on its throne by writing at the end of the arrow: "Moral: we must shoot at morality"?

\footnotetext{
${ }^{3}$ All published works of Nietzsche are quoted from the editions of Cambridge University Press.
} 
Or perhaps it has nothing to do with Nietzsche and his intentions, perhaps it is morality itself which - following a certain logic of shooting - raises the requirement: "I have to be attacked so that I would be strong again and sit firmly on my throne." Let us suppose that this is morality in Nietzsche that claims this; and let us also suppose that what is meant here is indeed Greek and Judeo-Christian virtue and morality - we must assume that, among other reasons, because Nietzsche has indeed incessantly shot at this kind of virtue and morality in his work and thought.

Now, how do the anarchists help the princes firmly back on their thrones again? It is generally true that every strong attack against certain phenomena or institutions always seems to bring a violent reaction - the defence forces of these institutions will increase, new means of defence and new strategies of attack will be invented, etc. - a fact that could be illustrated relatively easily with the help of historical examples. But it seems that such reactions, at least historically, will only have a short-term success - it is usually only for quite a short period of time that the princes sit "firmly back on their thrones" again, sooner or later they will be overthrown anyway. Does Nietzsche want morality to sit back on its throne only temporarily, this old JudeoChristian morality? Or perhaps we should not take the analogy to the princes so directly? Perhaps Nietzsche only wishes to point out that immoralists actually benefit morality? And, of course, it does not necessarily have to be the case that the princes, after having been attacked by anarchists, reclaim their thrones only temporarily.

Fortunately, there is a note from 1887 which is very similar to our arrow and might somewhat explain (or 
perhaps confuse) the matter. Nietzsche has noted down for himself:

Have I thereby harmed virtue? [...] As little as the anarchists harm princes: Only since they have been shot at do they sit tight on their thrones again [...] For thus has it been and always will be: one cannot benefit a thing any better than by persecuting it and hunting it down... This is - what I have done. (KSA 12, 10 [107])

We immediately notice similarities and differences compared to our arrow: here speaks an "I," Nietzsche as an individual, and not "we immoralists"; also the endings are quite a bit different and the word "morality" is missing completely. What do we do with these differences? Not necessarily much. In any case, it is obvious that the note is much clearer than our arrow: one could perhaps derive from it that Nietzsche indeed wanted to benefit virtue and has also done so by launching an attack on it. But does virtue get changed and modified when it is attacked and hunted down? To benefit virtue does not have to mean to help it back on its throne precisely as it was, unmodified and unchanged; it is very likely that also the princes will not remain the same when they have been attacked by the anarchists. However the case may be, it seems that virtue or morality has to be shot at in order to benefit it; to shoot at, just as to harm, means "to wound" or "to injure". Hence: the virtue has to be harmed in order to benefit it. The immoralists harm virtue and morality, but by harming them, they benefit them. Harming means benefiting and benefiting harming?

Hence, an insidious arrow the target of which cannot be determined easily, the target of which depends, among other things, on us, on our interpretative work. At this 
point, we should probably first pose a question: Who are the immoralists in Nietzsche's corpus, especially "we immoralists", and how do they relate themselves to virtue?

\section{MORALISTS AND / AS IMMORALISTS}

The aim here, of course, cannot be to determine with all the rigor and subtlety everything immoralists mean in Nietzsche's thinking, and what it is precisely that characterizes Nietzsche himself as an immoralist. In the following, I would only like to emphasize some of the most important features of immoralists - to become better equipped towards our arrow, we must at least have an idea about it - and the first thing we will notice is that people always find it difficult to understand and recognize who they really are, these immoralists.

Because they are moralists, the most genuine ones even - moralists as they should be. But certainly not preachers of morality. People (that is, the majority) who have seen too many preachers, fail to understand it - they consider them opposites of moralists and upbraid them as immoralists without realizing that the upbraided ones are actually moralists. They cannot realize it because such moralists dissect morality: "But he who wants to dissect has to kill; yet only for the sake of better knowledge, better judgement, better living [...]" (WS 19).

How does this relate to our arrow? Would the immoralists like to kill the morality after all? And when they are going to kill the old morality and old virtues, in what sense can they benefit them with their attacks? We cannot answer these questions yet; we should not forget, 
however, that what has been killed is not necessarily eliminated and abolished: the dead, perhaps precisely because he was killed, can, in certain ghostly manner, be more alive than the living. Not only harming a thing, but also killing it, can amount to benefiting it. And as we will see, in a certain sense, the morality and its virtues will indeed return to the immoralists.

The problem is that people do not know - because there has perhaps never been a "real" moralist yet - how and in what cases should one use the word "correctly" ${ }^{4}$. An ordinary parlance does not guarantee the "adequacy" or appropriateness of the word usage. After all, the "true" moralists - the immoralists - are certainly not the old ones: "The older moralists dissected too little and preached too much: which is why the moralists of today experience this confusion and its unpleasant consequences" (WS 19). According to Human, All Too Human, there is still something unpleasant for the moralists of today in the fact that they are being upbraided as immoralists. But soon, when "we immoralists" appear, the name is assumed - and with pride. Will the immoralists, with the adoption of the name, change? Will they no longer be moralists? There is no reason to suspect such a thing: the true moralists and immoralists keep dissecting "for the sake of better knowledge, better judgement, better living". It should not, therefore, surprise us that Nietzsche calls himself in his work moralist as well

\footnotetext{
${ }^{4}$ "Correctness" here is meant, of course, rhetorically. When Nietzsche uses the word "immoralist" differently than others, it has nothing to do with some kind of metaphysics of language, that is, he does not refer to some kind of neutral criteria of meaning. However, it is clear that he does not accept common parlance as necessarily adequate.

${ }^{5}$ Cf: „We are immoralists: we say that with pride.“ (KSA 13, 23 [12])
} 
as immoralist ${ }^{6}$; and the moralists he has constantly and vigorously attacked are supposedly always the old ones who apparently only knew how to preach.

Let us ask shortly: What characterizes these older moralists who, according to common language use, are indeed the moralists par excellence? They, for example, "accepted the morality venerated by the people as holy and true and only sought to systematize it" (KSA 9, 4 [107]; cf. BGE 186), no such moralist has yet dared to investigate the origins of this morality (KSA 9, 4[107]). Above all, they lack truthfulness - one could just call to mind how e.g. Kant, by means of his systematizations, lured „us along the clandestine, dialectical path that leads the way (or rather: astray) to his "categorical imperative"'(BGE 5). The old moralists did not understand much about virtue either, but we will come back to that. In any case, it can be said that all the Kantian moralists resemble priests in their wish to set humanity back „to an earlier level of virtue“, they were like crabs who were walking backwards while they should have probably guessed that each age has its own virtues (TI, Skirmishes of an Untimely Man 43). They are "dunces and dimwits" in their naivety - e.g. in their naïve belief that "unegoistic" and "egoistic" are opposed to each other, are opposites (EH, Why I write such good books 5). Could one conclude that they constantly delude themselves about oppositions in general? So it might seem: and from that one could perhaps derive further that the main reason why the older moralists were

\footnotetext{
${ }^{6}$ Cf: „Isn't a moralist the opposite of a Puritan? A thinker, that is, who treats morality as something questionable, question-mark-able, in short, as a problem? Shouldn't moralists be - immoral?" (BGE 228)
} 
not the "true" and "genuine" moralists was the fact that they did not know that in order to be a "true" moralist one has to be immoralist: they are, as it seems, metaphysicians who believe in oppositions and more specifically "in oppositions of values" (BGE 2).

Now, although fools will always say: "those are people without duties", the immoralists - moralists - are "people of duty", they "have been woven into a strong net and shirt of duties, and cannot get out of it" (BGE 226). Similarly to the thick-headed ones of Human, All Too Human, the fools of Beyond Good and Evil have difficulties to understand who and what they are, these immoralists, and what are actually duties. It is always also a problem of language. But which duties? A hint can be found in the new Preface of The Daybreak where Nietzsche says that also to him and other immoralists "thou shalt" still speaks, that also they are still men of conscience: "namely, that we do not want to return to which we consider outlived and decayed [...], be it called God, virtue, truth, justice, charity; [...]" (D, Preface 4). Specifically as men of this conscience do they still feel themselves bound to German integrity and piety of millennia, "even if as its most questionable and final descendants" (D, Preface 4). Hence, the immoralists are evidently characterized by extreme integrity and truthfulness, and also the aphorism from Beyond Good and Evil that we just quoted ("We, immoralists"), is immediately followed by an aphorism on honesty as seemingly the devilish virtue of the free spirits. The logic seems to be the following one: due to the (virtue) of honesty or truthfulness, they cannot turn back to 
virtue - the (virtue of) truthfulness ${ }^{7}$ forbids and prohibits them virtue. But what would happen if this truthfulness is paired with nitimur in vetitum (BGE 227)? We will come back to that. In any case, we have to assume that the free spirits are not very far from the immoralists.

Immoralists are also characterized by the fact that they have a completely different relationship to their enemies: while the Church, for example, wanted to destroy their enemies, the immoralists and anti-Christians think that they benefit "from the existence of the church" (TI, Morality as Anti-Nature 3). They do not negate easily, they stake their "honor on being affirmative" and they can "take advantage of even the disgusting species of idiot, the priests, the virtuous" (TI, Morality as anti-nature 6). At least so it is in Twilight of the Idols. Will things become perhaps more complicated when Nietzsche describes himself in Ecce Homo in the same breath as immoralist and as a "destroyer par excellence" (EH, Why I am a destiny 2)? And are the immoralists negators after all? In any event, Nietzsche writes quite clearly:

My word immoralist essentially entails two negations. First, I am negating a type of person who has been considered highest so far, the good, the benevolent, the charitable; second, I am negating a type of morality that has attained dominance and validity in the form of morality as such, - decadence morality or, to put it plainly, Christian morality. (EH, Why I am a destiny 4)

Is that a contradiction? Are the immoralists actually similar to the Church and wish to destroy their enemies?

\footnotetext{
${ }^{7}$ One could also differentiate "truthfulness" and the „virtue of truthfulness" (understood as a certain kind of attitude towards one's truthfulness), but I will not do it in this article.
} 
And how does that fit together with our arrow? However, there is no contradiction; one just needs to understand the nature of the Dionysian correctly: Nietzsche as an immoralist obeys his Dionysian nature, "which does not know how to separate doing no from saying yes" (EH, Why I am a destiny 2); similarly, one has to keep in mind that "negation and destruction are conditions of affirmation" (EH, Why I am a destiny 4). What would happen to interpreting Nietzsche if one was to accept this antimetaphysical logic which is doubtful of oppositions? Can one still determine, clearly and definitively, what it is that Nietzsche actually affirms and what it is that he denies? Supposing that there is a non-dialectical transition between affirmation and negation, that every affirmation can be a negation and vice versa, how could it ever be possible? One would probably like to reply: "But Nietzsche had to know it." Perhaps. However, one should not ignore the suspicion of immoralists "that the decisive value is conferred by what is specifically unintentional about an action, and that all its intentionality [...] only belongs to its surface and skin which, like every skin, reveals something but conceals even more" (BGE 32).

Thus, the annihilators and negators in Nietzsche's corpus cannot be taken at face value, and even less so when they are connected to immoralists - with the latter, as it turns out, everything becomes complicated and equivocal. That is why the people could never understand who they really are and what they want. 


\section{VIRTUE AND / AS A VICE}

Nietzsche's discourse on virtue is complicated, ambivalent, and includes many reversals and upheavals in comparison with the Greek and Christian tradition - for that reason, this problem cannot be treated comprehensively enough here. Nevertheless, we need ask: how do the immoralists relate themselves to virtue? We have seen in the Preface of The Daybreak that immoralists do have a specific duty resulting from extraordinary truthfulness that forbids them to return to virtue, God etc. How does this fit together with our arrow? If immoralists, due to (the virtue of) truthfulness, are not allowed to turn back to virtue, how can they benefit it and help it back on its throne? But they are allowed - at least in a certain way - to return to virtue, however, only under the condition that this truthfulness is paired with nitimur in vetitum and slightly enhanced.

In the following, I will mainly focus on two Nachlass notes from the autumn of 1887 which follow almost immediately to the note already quoted where Nietzsche asked if he has harmed virtue: we have thus a good reason to believe that they are all directly related to each other and to our arrow. Firstly, however, we have to take into account another note from the same period, so also from the autumn of 1887 where Nietzsche claims that virtue has lost its credibility and appeal today: "It demands too much extravagance and narrow-mindedness" (KSA 12, 9 [155]) and, as a result, has the conscience and honesty against itself. So once again conscience and truthfulness intervene. But for the unscrupulous ones, for people without conscience, as Nietzsche adds, it is precisely that (e.g. 
extravagance, narrow-mindedness, fake glitter etc.) which could be "its new attraction - from now on, it is what it has never been before, a vice" (KSA 12, 9 [155]). Yet another dissolution of opposites which makes the head spin. But in what sense has virtue become vice?

As already pointed out, the immoralists seem to have the virtue of truthfulness and honesty. It is even a "becoming virtue" (D 456), neither the Greeks nor the Christians had it. However, it did not come out of nowhere, it originated from the Greco-Judeo-Christina morality - there was truthfulness and honesty in morality itself. This truthfulness turns eventually against morality and exposes it as a "deep-rooted mendacity" (KSA 12, 5[71]), hence, moral as truthfulness forces to reject and abandon morality - morality against morality, "selfsublimation of morality" (D, Preface 4$)^{8}$. But when the morality as truthfulness has recognized the whole of morality, also the last stage and bits of it, morality as truthfulness included, as a lie - this would be the enhancement of truthfulness we spoke about - one has once again acquired, at least in principle, a permission to mendacity, to falsehood (KSA 12, 10 [110]).

Although truthfulness wishes to prohibit falsity constantly - i.e. although falsehood is always something forbidden in terms of morality as truthfulness - it no longer has the sole authority since it has been also, as part of the

\footnotetext{
${ }^{8}$ Nietzsche famously writes in the Preface of The Daybreak: „And if this book is pessimistic even into the realm of morality, even to the point of going beyond faith in morality - should it not for this very reason be a German book? For it does in fact exhibit a contradiction and is not afraid of it: in this book faith in morality is withdrawn - but why? Out of morality." (D, Preface 4)
} 
old morality, exposed as a lie and an illusion ${ }^{9}$. It remains to be, so to say, genealogically in the body, one cannot simply get rid of it; but despite that, the extreme honesty that would like to prohibit every lie has, by undermining its own authority, given us permission to falsehood again. So one also has once again permission to this beautiful falsehood of virtue. This means that the moral virtues have become immoral in terms of the last stage of morality as truthfulness, and precisely insofar as they have become immoral, they can be said to be justified again. As a formula: the ancient Greek and Judeo-Christian morality seems to be justified again as a form of immorality. For example: according to Nietzsche, it belongs to the strength of the $19^{\text {th }}$ century that it has become immoral to believe in God; but precisely that, the immorality of this belief, is, from now on, the best form of justification of the same belief (KSA 12, 10 [105]). Consequently, in terms of morality as truthfulness, also virtue (exposed as a lie) becomes a vice and something forbidden.

Is virtue now "classified in terms of its basic meaning" (KSA 12, 10 [110]) in the sense of virtus, of courage, of courage for the forbidden? Perhaps. In any case, insofar as it (as a falsehood) has become a vice and something

\footnotetext{
${ }^{9}$ Cf: „Why morality at all, if life, nature, and history are 'immoral'? No doubt, those who are truthful in that audacious and ultimate sense which faith in science presupposes thereby affirm another world than that of life, nature, and history; and insofar as they affirm this 'other world', must they not by the same token deny its counterpart, this world, our world?[...] But it is still a metaphysical faith upon which our faith in science rests -that even we knowers of today, we godless anti-metaphysicians, still take our fire, too, from the flame lit by the thousand-year old faith, the Christian faith which was also Plato's faith, that God is truth; that truth is divine [...] But what if this were to become more and more difficult to believe, if nothing more were to turn out to be divine except error, blindness, the lie - if God himself were to turn out to be our longest lie?" (GS 344; cf. GM III, 24)
} 
forbidden, it takes part in the fundamental immorality (supposedly in the sense of deception, of illusion, of cruelty) of being. But why is virtue "the most conceited, costly and rare form of vice" (KSA 12, 10 [110])? Maybe because the main reason why the immoralists strive after it is precisely that it has become vice and something forbidden. As we saw, Nietzsche pointed out that virtue has lost its attraction since we have our honesty and conscience against it. But now that it has been exposed as a form of immorality and appears to be something forbidden, Nietzsche has given it a new attraction - he has, at least for certain kind of people, made virtue interesting and attractive again. He writes:

Only after we have recognized everything as a lie, semblance, we again have acquired permission to this most beautiful of falsehoods, to virtue. There is no authority left that could forbid it to us: only after we have exposed virtue as a form of immorality, it has become justified again, - it is classified and qualified in terms of its basic meaning, it takes part in the fundamental immorality of all being, as a form of luxury of first degree, - as the most conceited, costly and rare form of vice. (KSA 12, 10 [110])

However, we need to ask: virtue in which sense, what kind of virtue? In the sense of the traditional morality and virtues? Will traditional morality simply return, this time, of course, as a form of immorality and something forbidden? In which case nothing would change; the only difference would be that now one seems to know that it is just a falsehood and mendacity. More precisely, only certain kind of people would know it, only the immoralists and truthful, only those for whom the traditional morality has become exposed. Hence, for the immoralists, the same old morality 
would be something forbidden and immoral (and for that reason, attractive) whereas for the majority of people it would be the only mandatory and binding morality? The same phenomenon and completely different attitudes? The immoralists would strive after this morality and feel attracted by it because it has become something forbidden and vice; the majority of people strive after the same morality, but they do that only because, to them, it seems to be the good in itself? And does that not remind us of the difference of differences, of the most significant difference there is, which, however, differentiates nothing: namely, of the difference between transcendental phenomenology and phenomenological psychology in Husserl? Concerning this difference, the world and all the phenomena remain the same - what matters is our attitude, whether we have performed epoché or not. Is it in this sense that Nietzsche and other immoralists wish to help the old morality back on its throne?

Apparently not. The understanding of virtues has also changed for the immoralists. The immoralists, having recognized that virtue is a mendacity, do not understand it as something universally valid, general and as an ideal for everybody. Could something forbidden be an ideal for everybody? This - the rareness and inimitability of virtue - is the first essential characteristic of how the immoralists understand virtue, and perhaps the most important difference from the traditional morality. A virtuous person, in the sense of the traditional morality, is actually not a person at all according to Nietzsche, he attains his value only by corresponding to a general pattern or schema (cf. KSA 12, 10 [205]). This seems to be true also with regard to Aristotelian 
virtues which all people would need to cultivate in themselves if they are to become happy. According to Aristotle, virtues as schemas determine also decisions, they contain certain criteria for decisions (e.g. the middle) so that a free and absolutely responsible decision is made impossible. However close Aristotelian megalopsychos can be said to be to Nietzsche's sovereign individual, in the last analysis, he is still only a certain schema, a general ideal. Hence, the preachers of the virtues of the traditional morality "strip virtue of its attraction of being something rare, inimitable, exceptional and non-average", in one word, "its aristocratic appeal" (KSA 12, 10 [109]).

But for Nietzsche as an immoralist, what matters is precisely the new attraction of virtue. Virtue has now become "unfavorable, imprudent, it isolates", "measured by the average standards of what is good for people, it corrupts the character, the head, the mind", shortly: "it is the worst vice, supposing that it is evaluated according to the harmfulness of its effects on others" (KSA 12, 10 [109]. Hence, we see that virtue does not only loose its generality but becomes even harmful to others, meaning: harmful to the old morality and its virtues which, in their universal validity, were supposed to be good and useful for the society as a whole. Thus it seems that virtue as the immoralists understand it is a form of immorality in a double sense: on the one hand, in terms of the final stage of morality, morality as honesty for such "new" virtues of immoralists are, after all, lies as well - on the other hand, in terms of the traditional morality and virtues which are not yet neutralized by truthfulness. Such virtues are vices and something forbidden in both senses. 
Hence, concerning Nietzsche and other immoralists, two kinds of falsehoods are at stake: on the on hand, the traditional virtues, on the other hand, the virtues as immoralists understand them - as mentioned, they are also falsehoods and "have our finest honesty against them" (KSA 12, 10 [110]). With regard to the last stage of morality, morality as truthfulness, which the immoralists have in their bodies and cannot simply free themeselves from, both of them should be understood as vice and something forbidden. Let us ask, then: why is it that the immoralists do not feel attracted the same way by the first falsehood as they do by the second? Or better: why are certain kinds of falsehoods not valid in the eyes of the immoralists if the whole of morality, every kind of moral embellishment, has been recognized as a lie and semblance? What differentiates one lie from another? It seems that the morality in the sense of traditional moral virtues is a kind of lie that convinces and persuades that not everything is a lie, and above all itself. It is a lie that presents itself as the only real and genuine reality; however, by doing that, it contradicts the fundamental insight of the immoralists that everything is a lie and semblance. By way of masking itself as the truth and something natural, it wants to hide the fundamental immorality of being as a whole. This, on the other hand, allowed it to pretend as if it was universally valid and something unchangeable - characteristics which quickly made it harmful to "life" (cf. KSA 13, 23 [13]). The falsehoods and lies which present themselves as the truth and hide the fundamental immorality of being, can become harmful to "life". But this fundamental immorality cannot be hidden from the immoralists, they have too much honesty in their bod- 
ies and minds. The difference between the old moral falsehoods on the one hand, and the new falsehoods still to be created, consists thus in the fact that the latter know what they are - falsehoods. Truthfulness is inherited and incorporated in the course of the long history of morality, one cannot simply get free of it, it will constantly unsettle and disturb all the new falsehoods as well, regard them „cum grano salis" (KSA 12, 10 [110]). Hence, the truthfulness, at least for the time being, will remain; however, it cannot be justified anymore because being as a whole has turned out to be fundamentally immoral, that is, a lie, illusion and semblance. It cannot be justified, but it nevertheless seems to be useful to the immoralists and "life" in general: it will not allow falsehoods which present themselves as something what they are not, as truths, for instance.

\section{CONCLUSION}

To summarize: the Immoralists have their conscience against virtue - they have realized that it demands too much extravagance and narrow-mindedness; it has also become uninteresting and boring ${ }^{10}$; it has lost its binding attraction. For these reasons, on the basis of this conscience and honesty, the immoralists shoot at virtue and morality until it is explicitly exposed as a lie and falsehood. In terms of morality as truthfulness, it is (as a lie) understood as a form of immorality and something forbidden, even a vice.

\footnotetext{
${ }^{10}$ Cf: „You will have to forgive me for having discovered that all moral philosophy so far has been boring and should be classified as a soporific - and that nothing has done more to spoil "virtue" for my ears than this tediousness of its advocates [...]." (BGE 228)
} 
But since this truthfulness of the immoralists is paired with nitimur in vetitum, virtue becomes once again interesting and attractive. As we saw, however, it does not remain exactly the same: it is also in the sense of the old morality which has not yet been canceled out by the honesty and truthfulness a form of immorality and vice.

Have not Levinas and Derrida - in a slightly different manner - done something similar? Have they not also tried to give a new attraction to morality? In this respect, one could think, for instance, of Derrida's discourse on free and absolutely responsible decisions which need to be taken without any universal moral rules and virtues, and which could even be vices according to those rules. In any case, responsibility, decision, hospitality and gift have been made so difficult, almost impossible, by Derrida that precisely this difficulty, impossibility and uncertainty could appeal as a new attraction of these moral phenomena - at least for those who can no longer find any excitement in the traditional morality, who feel bored with it. Thus, by making decision, gift, responsibility, hospitality paradoxical, by making ethics in general paradoxical, Derrida has perhaps made it interesting, effective and appealing again.

But it is not only about the new attraction of virtue, the immoralists have done more: having exposed everything (also the last stage of morality) as a lie, they have made virtue (as a lie) justified again. The principle of justification here seems to be the best possible adjustment to what is, to the immorality of life and being in general. One could perhaps say quite a few things against this kind of justification but this is not the topic of this paper.

In these two respects, so it seems, have the immoralists 
with their attacks and shots (far from harming it) benefited virtue and perhaps helped it back on its throne.

\section{REFERENCES}

NIETZSCHE, F. Sämtliche Werke. Kritische Studienausgabe in 15 Bänden, ed. by Giorgio Colli/Mazzino Montinari, Münschen/Berlin: DTV/De Gruyter, 1980.

. Human, All Too Human, ed. and transl. by R. J. Hollingdale, Cambridge: Cambridge University Press, 1986.

. On the Genealogy of Morality, ed. by K. AnsellPearson, transl. by C. Diethe, Cambridge: Cambridge University Press, 1994.

. Daybreak, ed. by M. Clark/B. Leiter, transl. by R. J. Hollingdale, Cambridge: Cambridge University Press, 1997.

. The Gay Science, ed. by B. Williams, transl. by J. Nauckhoff, Cambridge: Cambridge University Press, 2001.

. Beyond Good and Evil, ed. by R.-F. Horstmann/J. Norman, transl. by J. Norman, Cambridge: Cambridge University Press, 2002.

. The Anti-Christ, Ecce homo, Twilight of the Idols and Other Writings, ed. by A. Ridley/J. Norman, transl. by J. Norman, Cambridge: Cambridge University Press, 2005. 